Prepared in cooperation with San Bernardino Valley Municipal Water District

\title{
Hydrology of the Yucaipa Groundwater Subbasin: Characterization and Integrated Numerical Model, San Bernardino and Riverside Counties, California
}

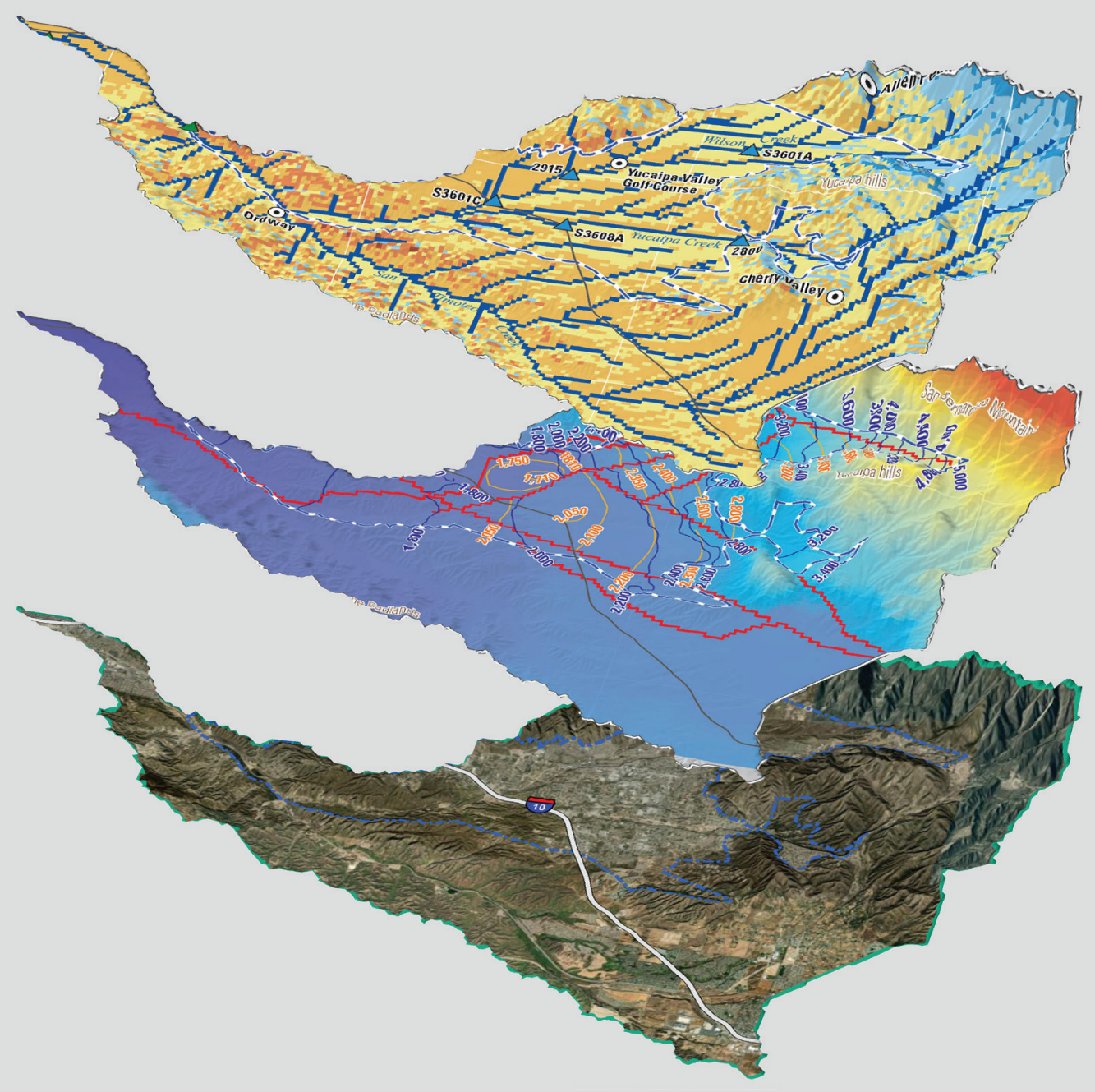

Scientific Investigations Report 2021-5118 
Cover: Visualization of the simulated domain and hydrologic components from the Yucaipa Integrated Hydrologic Model. 


\section{Hydrology of the Yucaipa Groundwater Subbasin: Characterization and Integrated Numerical Model, San Bernardino and Riverside Counties, California}

Edited by Geoffrey Cromwell and Ayman H. Alzraiee

Prepared in cooperation with San Bernardino Valley Municipal Water District

Scientific Investigations Report 2021-5118 


\section{U.S. Geological Survey, Reston, Virginia: 2022}

For more information on the USGS - the Federal source for science about the Earth, its natural and living resources, natural hazards, and the environment—visit https://www.usgs.gov or call 1-888-ASK-USGS.

For an overview of USGS information products, including maps, imagery, and publications, visit https://store.usgs.gov/.

Any use of trade, firm, or product names is for descriptive purposes only and does not imply endorsement by the U.S. Government.

Although this information product, for the most part, is in the public domain, it also may contain copyrighted materials as noted in the text. Permission to reproduce copyrighted items must be secured from the copyright owner.

Suggested citation:

Cromwell, G., and Alzraiee, A.H., eds., 2022, Hydrology of the Yucaipa groundwater subbasin—Characterization and integrated numerical model, San Bernardino and Riverside Counties, California: U.S. Geological Survey Scientific Investigations Report 2021-5118, 4 p., https://doi.org/10.3133/sir20215118.

ISSN 2328-0328 (online) 


\section{Acknowledgments}

The authors thank the San Bernardino Valley Municipal Water District for their cooperation on this project, including providing funding, expertise, and logistical support for data compilation and analysis. We also thank the respective staffs of the South Mesa Water Company, Western Heights Water Company, and the Yucaipa Valley Water District for providing hydrologic data and for their local and historical expertise about the area.

The authors thank U.S. Geological Survey colleagues for assistance in data compilation, analysis, and support, including: Claudia Faunt, Wes Danskin, Whitney Seymour, Jon Matti, Daniel Culling, Milissa Peterson, Sarah Roberts, and Lindsay Ellingson. 



\section{Contents}

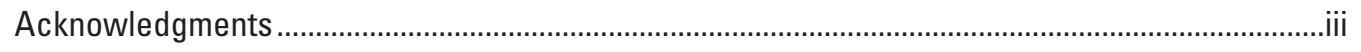

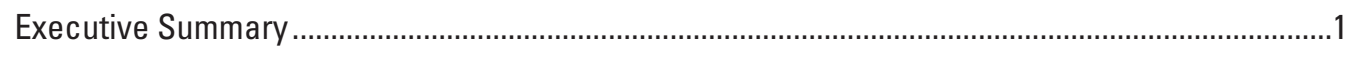

Hydrogeologic Characterization ...........................................................................................

Yucaipa Integrated Hydrologic Model Development..................................................................3

Yucaipa Integrated Hydrologic Model Results .........................................................................

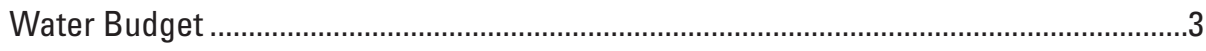

Groundwater Levels .................................................................................................. 4

Chapter A: Hydrogeologic Characterization of the Yucaipa Groundwater Subbasin

Chapter B: Yucaipa Valley Integrated Hydrological Model 


\section{Conversion Factors}

U.S. customary units to International System of Units

\begin{tabular}{|c|c|c|}
\hline Multiply & By & To obtain \\
\hline \multicolumn{3}{|c|}{ Length } \\
\hline foot $(\mathrm{ft})$ & 0.3048 & meter $(\mathrm{m})$ \\
\hline mile (mi) & 1.609 & kilometer (km) \\
\hline \multicolumn{3}{|c|}{ Area } \\
\hline square mile $\left(\mathrm{mi}^{2}\right)$ & 259.0 & hectare (ha) \\
\hline square mile $\left(\mathrm{mi}^{2}\right)$ & 2.590 & square kilometer $\left(\mathrm{km}^{2}\right)$ \\
\hline \multicolumn{3}{|c|}{ Volume } \\
\hline acre-foot (acre-ft) & 1,233 & cubic meter $\left(\mathrm{m}^{3}\right)$ \\
\hline acre-foot (acre-ft) & 0.001233 & cubic hectometer $\left(\mathrm{hm}^{3}\right)$ \\
\hline \multicolumn{3}{|c|}{ Flow rate } \\
\hline acre-foot per year (acre-ft/yr) & 1,233 & cubic meter per year $\left(\mathrm{m}^{3} / \mathrm{yr}\right)$ \\
\hline acre-foot per year (acre-ft/yr) & 0.001233 & cubic hectometer per year $\left(\mathrm{hm}^{3} / \mathrm{yr}\right)$ \\
\hline inch per year (in/yr) & 25.4 & millimeter per year (mm/yr) \\
\hline
\end{tabular}

\section{Abbreviations}

$\begin{array}{ll}\text { DWR } & \text { California Department of Water Resources } \\ \text { HRU } & \text { hydrologic response units } \\ \text { MAR } & \text { Managed Aquifer Recharge } \\ \text { TDS } & \text { Total dissolved solids } \\ \text { USGS } & \text { U.S. Geological Survey } \\ \text { YIHM } & \text { Yucaipa Integrated Hydrologic Model } \\ \text { YVW } & \text { Yucaipa Valley watershed }\end{array}$




\title{
Hydrology of the Yucaipa Groundwater Subbasin: Characterization and Integrated Numerical Model, San Bernardino and Riverside Counties, California
}

\author{
Edited by Geoffrey Cromwell and Ayman H. Alzraiee
}

\section{Executive Summary}

Water management in the Santa Ana River watershed in San Bernardino and Riverside Counties in southern California is a complex task with various water purveyors navigating geographic, geologic, hydrologic, and political challenges to provide a reliable water supply to stakeholders. As the population has increased throughout southern California, so has the demand for water. The Yucaipa groundwater subbasin (hereafter referred to as "Yucaipa subbasin"), one of nine groundwater subbasins in what the California Department of Water Resources (DWR) refers to as the Upper Santa Ana Valley groundwater basin (California Department of Water Resources, 2016; the DWR naming convention is used within this report), is no exception; steady population growth since the 1940s and changes in water use has forced local water purveyors to regularly adapt their water infrastructure to meet demand. Groundwater has historically been the dominant source of water in the Yucaipa subbasin although recently, imported water via the California State Water Project has augmented the total water supply. Despite the influx of imported water, overall demand for groundwater continues to rise, and there is concern by local water managers that groundwater levels may adversely impact water supply and (or) decline to a point where it will be uneconomical to produce water, severely limiting the ability of local agencies to meet water-supply demand.

To better understand the hydrogeology and water resources in the Yucaipa subbasin, the U.S. Geological Survey (USGS) and the San Bernardino Valley Municipal Water District initiated a cooperative study to understand the hydrogeologic system of the Yucaipa subbasin and in the encompassing Yucaipa Valley watershed (YVW). A three-dimensional hydrogeologic framework model was constructed to quantify the structure and extent of hydrogeologic units. Historical and present-day groundwater conditions were characterized to evaluate the groundwater-flow system. Lastly, the Yucaipa Integrated Hydrological Model (YIHM) was developed to simulate the integrated surface-water and groundwater systems, including natural and anthropogenic (that is, human influenced) recharge and discharge throughout the study area from 1947 to 2014.

The Yucaipa subbasin is an inland groundwater basin located about 12 miles (mi) southeast of the City of San Bernardino and about 75 mi east of Los Angeles, California. The subbasin encompasses about 39 square miles $\left(\mathrm{mi}^{2}\right)$, including the City of Yucaipa. The geographic extent of the Yucaipa subbasin was established by the California Department of Water Resources, who defined the boundaries of the subbasin based on hydrogeologic transitions between crystalline rock and basin-fill sediments, active fault strands, surface-water drainage divides, and a portion of an adjudicated groundwater management boundary. Two groundwater subbasins of the Upper Santa Ana Valley groundwater basin are adjacent to the Yucaipa subbasin, the San Bernardino groundwater subbasin to the west and the San Timoteo groundwater subbasin to the south.

The Yucaipa subbasin is encompassed by the YVW, which is in turn comprised of three sub-watersheds that represent surface-water flow across and within the Yucaipa subbasin. Although the Yucaipa subbasin is the specific area of interest for this study, the entire YVW was considered for the purposes of characterizing the hydrogeology of the Yucaipa subbasin and for development of the YIHM.

The purposes of this report are to (1) describe the hydrologic and hydrogeologic settings of the Yucaipa subbasin and aquifer system, (2) describe the construction and calibration of the fully coupled groundwater and surface-water flow model for the Yucaipa subbasin and the encompassing YVW, referred to as the YIHM, and (3) present numerical results, including water budgets and hydraulic heads, and the effect of pumping and climate stresses (precipitation and temperature) on water-budget components. 


\section{Hydrogeologic Characterization}

Three basin-fill hydrogeologic units comprise the aquifer system in the Yucaipa subbasin. Underlying these basin-filling units is crystalline basement, which likely has a continuous, thin layer of weathered saprolitic material along its upper surface. The three basin-fill hydrogeologic units (from oldest [deepest] to youngest [most shallow]) are referred to as (1) consolidated sedimentary materials, (2) unconsolidated sediment, and (3) surficial materials. Consolidated sedimentary materials are more compacted, cemented, and have a greater abundance of clay and silt relative to the overlying unconsolidated sediment and surficial materials, making this unit the least permeable of the three. The unconsolidated sediment represents the primary aquifer unit, with more coarse- than fine-grained material and indicating a likelihood of high permeability and capacity for groundwater flow and storage. The surficial materials consist of unconsolidated, coarse-grained materials, and this unit is generally located above the water-table; therefore, this unit is unlikely to contribute to groundwater storage but permits rapid recharge to the groundwater table. Crystalline basement is the basal unit in the Yucaipa subbasin but should not be considered hydrologically impermeable. These rocks do not host large volumes of groundwater, but small-scale joints and fractures can serve as conduits to groundwater flow, and the presence of weathered saprolitic material may affect groundwater flow through the aquifer.

A series of faults and groundwater barriers dissect and bound the Yucaipa subbasin. These faults and barriers delineate 12 groundwater subareas (hereafter referred to as "subareas"), 7 of which comprise the majority of the aquifer system. Several faults and barriers have been shown or interpreted to inhibit groundwater flow (such as the Chicken Hill fault, Yucaipa graben complex, and the Cherry Valley thrust fault), as have geologic structures such as the folds associated with the Miocene Banning fault and the South Mesa barrier.

Present-day recharge to the basin-fill aquifer occurs primarily as deep percolation of mountain-front runoff and infiltration of streamflow in the Oak Glen, Triple Falls Creek, and Wilson Creek subareas in the northeastern part of the Yucaipa subbasin. Underflow from crystalline basement and infiltration from precipitation are additional sources of natural recharge to the basin-fill aquifer. Estimates of historical annual recharge in the Yucaipa subbasin generally range from about 7,000 acre-feet per year (acre-ft/yr) to more than about 13,000 acre-ft/yr. Water from northern California has been imported to the Yucaipa subbasin since 2002, has been applied directly as managed aquifer recharge (MAR) to the Wilson Creek and Oak Glen Creek spreading basins, and has been treated and used to augment the municipal water supply and reduce the demand for groundwater pumping. Between 2002 and 2014, about 69,200 acre-feet (acre-ft) of water was imported to the subbasin; about 17,900 acre-ft of this amount was applied as MAR. Pumpage estimates during 1947-2014 ranged from about 4,000 acre-ft in 1947 to a high of about 18,500 acre-ft in 2002. The average annual amount of groundwater removed from the Yucaipa subbasin by pumping during 1947-2014 was estimated to be about 12,800 acre-ft/yr, which was greater than most estimates of annual recharge to the subbasin.

The predominant direction of groundwater flow under historical and present-day conditions was from the northeastern subareas adjacent to the San Bernardino Mountains and the low hills just east of the City of Yucaipa (hereafter referred to as "Yucaipa hills"), to the west and south toward San Timoteo Creek, and eventually toward the Santa Ana River west of the subbasin. Natural discharge of deep groundwater occurs as evapotranspiration, and subsurface outflow along the western margin of the Yucaipa subbasin to the adjacent San Bernardino subbasin. Estimates of subsurface outflow across the western margin ranged from about 3,500 to 20,000 acre-ft/yr during 1905-2015; there was an overall decline in the estimated outflow values during this time, likely attributed to a steady decline in groundwater levels caused by pumping. The long-term extraction of groundwater has caused groundwater levels to decrease by nearly 200 feet (ft) since the 1940s in parts of the Calimesa and Western Heights subareas. Groundwater levels in subareas near the areas of natural recharge (such as the Oak Glen, Wilson Creek, and Crafton subareas) have declined by much less, and in some cases increased due to the application of MAR and reduction in pumping associated with the importation of water from northern California.

Four groundwater types were identified in the Yucaipa subbasin, the chemical character of which varied depending on the source and location of recharge. Most groundwater in the Yucaipa subbasin was calcium-bicarbonate-type water and was locally recharged from deep percolation of mountain-front runoff, streamflow, and precipitation. Groundwater recharged to the basin-fill aquifer through crystalline basement was sodium-sulfate-type water and was identified in deep wells in the Calimesa subarea; samples of this groundwater type did not have detectable tritium, indicating pre-modern recharge age. Groundwater in a perched aquifer in the Western Heights subarea was sulfate-rich, calcium-bicarbonate-type water. Water imported from northern California and applied as MAR in the Wilson Creek subarea was chloride-type water. At least some samples of all groundwater types, with the exception of water recharged through crystalline basement, had detectable tritium, indicating that most groundwater types had modern recharge ages. Concentrations of total dissolved solids (TDS) of groundwater ranged from about 225 to 1,120 milligrams per liter; groundwater samples with lower TDS concentrations generally were from wells near sources of natural recharge, and samples with the highest TDS concentrations were from deep wells near the contact with the crystalline basement rocks. 


\section{Yucaipa Integrated Hydrologic Model Development}

The YIHM is needed to better understand and quantify the hydrologic system of the Yucaipa subbasin and to quantify the effects of historical and potential water-resource development induced by climate changes and human-related activities, respectively. The YIHM was developed using the USGS Groundwater and Surface-water FLOW model (GSFLOW). GSFLOW simulation software consists of two integrated model components: (1) a watershed-component model developed by using Precipitation Runoff Modeling System (PRMS) and (2) a groundwater-component model developed by using MODFLOW-NWT. The integrated surface-water and groundwater model was developed for the YVW, a 121- $\mathrm{mi}^{2}$ watershed that encompasses the Yucaipa subbasin.

The watershed-component of the YIHM was developed using the PRMS and performs a continuous daily simulation of the hydrologic processes of the land surface (including vegetation cover, soil-zone, and impervious and pervious areas). The watershed-component of the YIHM model included 14,012 hydrologic response units (HRUs) discretized to match the $492 \mathrm{ft}$ on a side, grid-cell layout of the underlying groundwater-component model. The land surface HRUs are used to represent the spatial variability of land-surface elevation, slope, and aspect; vegetation type and cover; land use; distribution of precipitation, temperature, and solar radiation; soil morphology and geology; and flow direction. The HRUs were connected to a flow drainage network that routes surface water to one location of outflow on western portion of San Timoteo Creek near the City of Redlands. The daily climate input used in the YIHM was distributed from climate stations to all HRUs to account for spatial variability of precipitation and air temperature.

The groundwater-component model simulates water flow and storage in the unsaturated zone, the saturated zone, and the stream network. The groundwater-component model characteristics included a finite-difference grid of 134 rows and 237 columns with uniform, square model cells with a dimension of about $492 \mathrm{ft}$ on each side. There were four layers of variable thickness. Aquifer properties were spatially defined by hydrogeologic units on the basis of previously published geology and borehole texture data. Boundary conditions included no-flow and head-dependent flow boundaries to allow for subsurface flow into or out of the YVW, as appropriate. A network of faults was simulated in the model as partial barriers to groundwater flow. The Yucaipa subbasin was divided into 12 subareas to aid in the analysis of groundwater budget conditions. Groundwater inflow included recharge (resulting from deep percolation of precipitation and return flow) through the unsaturated to saturated zone, recharge from streams, and subsurface flow from adjacent groundwater basins. Groundwater outflow included pumpage, base flow, groundwater evapotranspiration, surface leakage, and subsurface flow to adjacent groundwater basins and subbasins.
The YIHM was calibrated by using an Ensemble Smoother, Parameter Estimation software (PEST), and an iterative trial-and-error approach of adjusting model parameters to achieve a reasonable fit between simulated and measured solar radiation, potential evapotranspiration, average streamflow, and transient groundwater levels during the period 1970-2014. The calibration process for the YIHM included adjusting the initial estimates of the land-surface properties, soil-zone properties, stream-channel properties, aquifer properties, general-head boundary properties, and fault characteristics.

\section{Yucaipa Integrated Hydrologic Model Results}

The YIHM was used to simulate the daily water budget for a continuous 67-year period that began January 1, 1947, and ended December 31,2014. The calibrated YIHM was used to derive components of the daily water budgets for the components of the integrated model for calendar years 1970-2014 (long-term average), with particular attention given to groundwater budgets for dry and wet periods. The YIHM also was used to assess the effects of pumping and climate stresses on hydrologic-budget components in 12 subareas within the Yucaipa subbasin.

\section{Water Budget}

Inflow sources to the YIHM include precipitation, anthropogenic recharge, and lateral groundwater inflow. Outflow components include evapotranspiration, groundwater pumping, streamflow, and lateral groundwater outflow. Results of water budget analysis for the integrated hydrologic system (including watershed and groundwater systems) during the period 1970-2014 showed that the major inflow source is precipitation with annual average volume of about 78,400 acre-ft/yr, equivalent to basin-wide average of 12.0 inches per year (in/yr). Evapotranspiration was the largest outflow from the YIHM with annual average of about $60,400 \mathrm{acre}-\mathrm{ft} / \mathrm{yr}(9.2 \mathrm{in} / \mathrm{yr})$, or 76 percent of the basin-wide precipitation. Groundwater pumping was the second largest outflow with annual average of 15,800 acre-ft/yr. The differences between all inflows and outflows were used to estimate simulated storage changes. Results showed that the average change in water storage within the YIHM during the period 1970-2014 was about -705 acre-ft/yr; most of the storage change was in the groundwater storage and soil zone. Overall, results of the integrated model budget analysis showed that climate stresses (precipitation, temperature, and evapotranspiration) and anthropogenic stresses (groundwater pumping and managed aquifer recharge) were the major drivers for the spatial and temporal variability of water storage within the hydrologic system. The simulated water storage in the YIHM increased during the wet periods of 1978-83 and 1991-98 and decreased during the dry periods of 1984-90 and 1999-2000. 
The groundwater component of the YIHM modeled the saturated zone and unsaturated zone. Inflow components of the groundwater model budget included (1) infiltration from precipitation, (2) leakage from streams where the water table was below the elevation of the streambed, (3) anthropogenic recharge, which included MAR and return flow from wastewater and irrigation, and (4) subsurface inflow from adjacent groundwater subbasins. Recharge was the largest inflow source into the saturated groundwater zone with a basin-wide average of 23,100 acre-ft/yr (3.5 in/yr) during the period 1970-2014. Outflow components included groundwater pumping, groundwater evapotranspiration, surface leakage, and subsurface outflow to adjacent groundwater subbasins.

The change in simulated groundwater storage was largely controlled by the combined effects of groundwater pumping and recharge. Simulation results indicated that during the predominantly wet periods $1978-83$ and 1991-98, the cumulated gains in groundwater storage reached about 150,000 acre-ft and 180,000 acre-ft, respectively. Most of this storage gain was depleted after 1998 from increased groundwater pumping and sporadic dry periods between 1999 and 2010. Starting in 2002, water was imported from northern California to augment the municipal groundwater demand. Imported water applied as MAR at the Wilson Creek and Oak Glen Creek spreading basins and reduction of groundwater pumping after 2002 resulted in increased groundwater storage in some subareas such as Wilson Creek, Gateway, Crafton, and Oak Glen. The simulated water budget for subareas showed that Calimesa, Triple Falls Creek, Live Oak, Wildwood, and Smiley Heights subareas showed some increase in cumulative storage, but the 2014 storage values were still lower than the 2008 values. Simulated groundwater storage in Western
Heights, Cherry Valley, and Sand Canyon subareas steadily decreased during most of the simulated period 1970-98; however, the rate of groundwater storage depletion decreased after 2007.

\section{Groundwater Levels}

Groundwater pumping and climate conditions were the main drivers of changes in groundwater levels in the YIHM. In the period from 1978 to 1983, groundwater levels increased in most subareas (except for Western Heights and Sand Canyon subareas) in response to the generally wet seasons that prevailed during this period. This observation is consistent with the groundwater budget analysis from the YIHM. A combination of increased pumping and relatively dry seasons during the periods 1984-90 and 1999-2002 resulted in a decline in groundwater levels. Some of the subareas demonstrated delayed increases in groundwater levels following the importation of water that started in 2002. Observed and simulated groundwater levels during 2008-14 showed an increase of about $150 \mathrm{ft}$ in some parts of the upgradient subareas (such as the Wilson Creek and Gateway subareas). Groundwater levels in parts of the downgradient subareas (such as the Calimesa subarea) experienced a smaller increase during the same period. Simulated and observed groundwater levels in the Western Heights subarea steadily decreased during 1970-2014, resulting in a total reduction of about $120 \mathrm{ft}$. After 2010, the rate of decline of groundwater levels decreased following reductions in groundwater pumping. 
For more information concerning the research in this report, contact the

Director, California Water Science Center

U.S. Geological Survey

6000 J Street, Placer Hall

Sacramento, California 95819

https://ca.water.usgs.gov

Publishing support provided by the

U.S. Geological Survey Science Publishing Network, Sacramento Publishing Service Center 


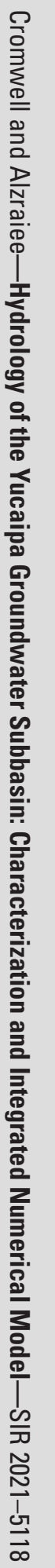

